\title{
Intra-dermal immunisation with SIV gag-based vaccines alone inhibits acquisition of SIVmac251
}

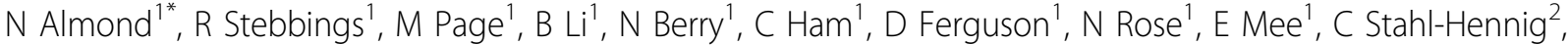

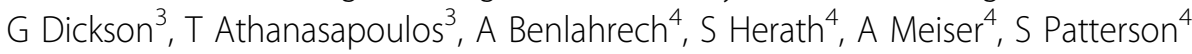

From AIDS Vaccine 2012

Boston, MA, USA. 9-12 September 2012

\section{Background}

It is increasingly recognised that effective anti-viral cell mediated immunity depends not only on the frequency of antigen specific $\mathrm{T}$ cells, but also on the quality of these $T$ cells. We have evaluated a vaccine protocol involving DNA prime and Adenoviral vector boost to deliver SIV gag in MHC typed Mauritian derived Macaca fascicularis.

\section{Methods}

Groups of 8 macaques were immunised 3 times on weeks $0,4,8$ with $100 \mu \mathrm{g}$ purified plasmid DNA designed to express SIVmac239 derived gag under the control of the CMV immediate early promoter. Three different SIV gag vaccines were compared. The DNA plasmids expressed native SIVmac239gag, ubiquinated SIVmac239 gag or fragmented, ubiquinated SIVmac239 gag derived peptides. On week 19, the groups were boosted with $10 \mathrm{e} 7$ infectious units recombinant Ad 5 expressing the same SIV Gag antigens. Cell mediated immunity was assessed after each immunisation and after virus challenge. At week 23, all vaccinated macaques, along with a group of naive challenge controls began 10 weekly, atraumatic challenges via the rectal mucosal with $150 \mathrm{TCD}_{50}$ SIVmac251. $^{2}$

\section{Results}

Delivery of this vaccine via the intra-dermal route elicited CD8 and CD4 T cell responses. Moreover, approximately $50 \%$ of antigen specific CD4+ $\mathrm{T}$ cells expressed the mucosal homing marker alpha4 beta7. When vaccinated macaques were exposed to a stock of uncloned SIVmac251 that had been propagated on simian PBMC's, by repeated low dose challenge via the intra-rectal route, a significant delay (Wilcoxon test; $\mathrm{p}=0.015$ ) in acquisition

NIBSC-HPA, Potters Bar, Hertfordshire, UK

Full list of author information is available at the end of the article of SIV was obtained amongst vaccinated macaques compared with naive controls challenged in a similar manner. Furthermore, peak viral loads amongst vaccinated macaques were significantly lower than challenge controls (Kruskal-Wallis test; $\mathrm{p}=0.010$ ).

\section{Conclusion}

We are investigating whether the route of immunisation was crucial to the vaccine's success.

\section{Author details}

${ }^{1}$ NIBSC-HPA, Potters Bar, Hertfordshire, UK. '2DPZ, Göttingen, Germany. ${ }^{3}$ Royal Holloway, University of London, London, UK. ${ }^{4}$ Imperial College, London, UK.

Published: 13 September 2012

\section{doi:10.1186/1742-4690-9-S2-O49}

Cite this article as: Almond et al:: Intra-dermal immunisation with SIV gag-based vaccines alone inhibits acquisition of SIVmac251.

Retrovirology 2012 9(Suppl 2):O49.

Submit your next manuscript to BioMed Central and take full advantage of:

- Convenient online submission

- Thorough peer review

- No space constraints or color figure charges

- Immediate publication on acceptance

- Inclusion in PubMed, CAS, Scopus and Google Scholar

- Research which is freely available for redistribution

\section{C)

@ 2012 Almond et al; licensee BioMed Central Ltd. This is an Open Access article distributed under the terms of the Creative Commons Attribution License (http://creativecommons.org/licenses/by/2.0), which permits unrestricted use, distribution, and reproduction in any medium, provided the original work is properly cited. 